Article

\title{
Removal of Pyridine, Quinoline, and Aniline from Oil by Extraction with Aqueous Solution of (Hydroxy)quinolinium and Benzothiazolium Ionic Liquids in Various Ways
}

\author{
Zhaojin Zhang ${ }^{1}$, Yinan $\mathrm{Li}^{1}{ }^{1}$, Jing Gao ${ }^{1}$, Alula Yohannes ${ }^{2}$, Hang Song ${ }^{1}$ and Shun Yao ${ }^{1, *}$ (i) \\ 1 School of Chemical Engineering, Sichuan University, Chengdu 650061, China; \\ 2021223075227@stu.scu.edu.cn (Z.Z.); 2018141494035@stu.scu.edu.cn (Y.L.); oxfordys@yeah.net (J.G.); \\ pharmposter2012@163.com (H.S.) \\ 2 College of Natural Science, Wolkite University, Wolkite P.O. Box 07, Ethiopia; alulayhnns@gmail.com \\ * Correspondence: cusack@scu.edu.cn; Tel.: +86-028-8540-5221
}

Citation: Zhang, Z.; Li, Y.; Gao, J.; Yohannes, A.; Song, H.; Yao, S. Removal of Pyridine, Quinoline, and Aniline from Oil by Extraction with Aqueous Solution of

(Hydroxy)quinolinium and Benzothiazolium Ionic Liquids in Various Ways. Separations 2021, 8, 216 https://doi.org/10.3390/ separations 8110216

Academic Editors: Sascha Nowak and Attilio Naccarato

Received: 27 September 2021

Accepted: 9 November 2021

Published: 12 November 2021

Publisher's Note: MDPI stays neutral with regard to jurisdictional claims in published maps and institutional affiliations.

Copyright: (c) 2021 by the authors. Licensee MDPI, Basel, Switzerland. This article is an open access article distributed under the terms and conditions of the Creative Commons Attribution (CC BY) license (https:/ / creativecommons.org/licenses/by/ $4.0 /)$.

\begin{abstract}
Based on above background, quinolinium, 8-hydroxy-quinolinium, and benzothiazolium ionic liquids, containing the acidic anions of methanesulfonate $\left(\left[\mathrm{CH}_{3} \mathrm{SO}_{3}\right]^{-}\right)$, phosphate $\left(\left[\mathrm{H}_{2} \mathrm{PO}_{4}\right]^{-}\right)$, $p$-toluenesulfonate $\left([p-\mathrm{TSA}]^{-}\right)$, and bisulfate $\left(\left[\mathrm{HSO}_{4}\right]^{-}\right)$were synthesized. After comparison, the aqueous solution of benzothiazole bisulfate $[\mathrm{HBth}]\left[\mathrm{HSO}_{4}\right]$ was selected as the most ideal extractant for removing pyridine and aniline. Meanwhile, benzothiazole bisulfate $[\mathrm{HBth}]\left[\mathrm{HSO}_{4}\right]$ solution was found as the best one for removing quinoline from simulated oil. Then, the single stage extraction and two-step extraction were used in the extraction for the simulated oil containing pyridine, quinoline or aniline, and their mixture, respectively. Their denitrogenation performance on their $\mathrm{N}$-removal effect was compared on the basis of structural features, and main extraction conditions were further investigated, including mass ratio of IL to water, mass ratio of IL to oil, and temperature. Furthermore, the extraction process was described by two kinetic equations. Recovery and reuse of IL were realized by back-extraction and liquid-liquid separation, and a related mechanism was speculated, according to all the experimental results. Finally, based on the developed method for preparing complex adsorbent tablets, corresponding immobilized IL was used to remove target objects, by solid phase extraction, in order to extend separation ways, which was more easily recovered after extraction.
\end{abstract}

Keywords: ionic liquids; denitrogenation; extraction; pyridine; quinoline; aniline; simulated oil

\section{Introduction}

With the in-depth study on sustainable chemistry, oil denitrogenation has aroused wide spread concern. Nitrogen exists in various forms in crude oil, which are mainly divided into non alkaline and alkaline nitrides, according to their alkalinity [1,2]. Basic nitrides mainly include aniline, pyridine, quinoline, and their derivatives; non-alkaline nitrides often include carbazole, pyrrole, indole, and their derivatives [3-5]. With the rapid development of the world economy, the demand for fuel oil is also increasing, but the nitrides contained in oil products will lead to some problems, especially in the following aspects:

(1) The nitrides in the oil has a great impact on the properties of the oil. Related compounds can play a catalytic role and accelerate the reaction of substances in the oil, which cause the deterioration of the oil and easily generate colloidal precipitation. All of these can result in the decrease in oil quality and storage stability meanwhile affect its performance in use. In addition, nitrides will also corrode the equipment and affect oil service life during storage or transportation [6].

(2) Nitrogen compounds in oil products are discharged into the atmosphere in the form of $\mathrm{NO}_{\mathrm{x}}$ after combustion, and the latter can form acid rain in combination with water molecules in the air, which is very harmful to crops, together with buildings, and 
can cause water pollution [7,8]. More seriously, $\mathrm{NO}_{2}$ can cause organ diseases, reduce the resistance of immune functions, and affect the health of human body. In addition, $\mathrm{NO}_{\mathrm{x}}$ and hydrocarbons exposed to strong sunlight and ultraviolet radiation in the atmospheric environment will lead to more severe environmental problems, such as photochemical smog and thinning of the ozone layer. It is advisable to remove nitrogen compounds in advance rather than let them discharge [9].

(3) In the oil secondary processing, including catalytic cracking and hydrofining, the competitive adsorption of basic nitrides and sulfides in oil products, on the active sites of the catalyst, leads to the degradation of the selectivity and working efficiency of precious metals and even to the poisoning and loss of the catalyst [10]. The result makes the deep hydrogenation process difficult and easy to form ammonium salt, which can block the pipelines in the reaction process.

The traditional ways to remove nitrogen compounds in oil products mainly include hydrogenation and non-hydrogenation denitrogenation technologies. The former refers to the conversion of nitrogen-containing compounds into ammonia and water by reaction with hydrogen under the action of catalyst (e.g., $\mathrm{Co}-\mathrm{Ni}-\mathrm{Mo} / \mathrm{Al}_{2} \mathrm{O}_{3}, \mathrm{Ni}-\mathrm{W} / \mathrm{Al}_{2} \mathrm{O}_{3}$ ) [11]. At the initial stage, the catalytic denitrogenation efficiency of this technique was around $20 \%$, which can reach higher than $70 \%$ after gradual improvement in recent years [12]. The oil quality produced by this technology has some problems, such as poor stability, short storage cycle, and so on. In the operation process, the conditions are harsh, and the amount of hydrogen consumed is large, so the relative risk is increased. In addition, energy consumption and cost are great. Due to these limitations of hydrodenitrogenation process, non-hydrodenitrogenation technologies are gradually developed as substitute means. It mainly includes extraction, acid refining, adsorption, microorganisms, and other methods $[13,14]$. Moreover, the hybrid of them is considered more effective; e.g., the denitrifier was prepared by acidic agent, complexant, and demulsifier. Table 1 describes the details of various non-hydrodenitrogenation methods for comparison.

Table 1. Comparison of non-hydrodenitrogenation methods.

\begin{tabular}{|c|c|c|c|c|c|}
\hline Ways & Principles & Advantages & Disadvantages & Denitrifiers & Ref \\
\hline Extraction & $\begin{array}{l}\text { Based on the principle } \\
\text { of "like dissolves like", } \\
\text { the purpose of } \\
\text { separation and } \\
\text { purification is } \\
\text { achieved through } \\
\text { selective dissolution }\end{array}$ & $\begin{array}{l}\text { Nitrogen compounds } \\
\text { can be removed under } \\
\text { normal pressure, and } \\
\text { the good resistivity } \\
\text { and appearance of oil } \\
\text { can be achieved }\end{array}$ & $\begin{array}{l}\text { The reduction of } \\
\text { hydrocarbon } \\
\text { compounds limits the } \\
\text { application of oil } \\
\text { products, and the } \\
\text { extraction efficiency } \\
\text { needs to be improved }\end{array}$ & $\begin{array}{l}\text { Furfural, phenol, } \\
\text { dimethyl sulfoxide, } \\
\text { and dimethyl } \\
\text { formamide, etc. }\end{array}$ & {$[15,16]$} \\
\hline Acid refining & $\begin{array}{l}\text { Strong } \\
\text { organic/inorganic } \\
\text { acids and basic } \\
\text { nitrogen-containing } \\
\text { substances form } \\
\text { insoluble salts in oil }\end{array}$ & $\begin{array}{l}\text { Low processing cost } \\
\text { and loss of oil, which } \\
\text { can remove colloid } \\
\text { and other impurities } \\
\text { in oil }\end{array}$ & $\begin{array}{l}\text { Acids can corrode the } \\
\text { equipment and the } \\
\text { acidic residue is } \\
\text { difficult to treat, which } \\
\text { is not friendly to the } \\
\text { environment and } \\
\text { operators }\end{array}$ & $\begin{array}{l}\text { Inorganic acids, } \\
\text { trifluoroacetic acid, } \\
\text { oxalic acid and solid } \\
\text { acid, etc. }\end{array}$ & {$[17,18]$} \\
\hline $\begin{array}{l}\text { Complexation } \\
\text { separation }\end{array}$ & $\begin{array}{l}\text { Lewis acid-base theory } \\
\text { and complexation }\end{array}$ & $\begin{array}{l}\text { The dosage of } \\
\text { complexing agent is } \\
\text { small and the removal } \\
\text { efficiency is high }\end{array}$ & $\begin{array}{l}\text { The complex can } \\
\text { dissolve in the oil, and } \\
\text { the subsequent } \\
\text { separation is difficult }\end{array}$ & $\begin{array}{l}\text { Transition metal } \\
\text { halides such as ferric } \\
\text { chloride }\end{array}$ & {$[19,20]$} \\
\hline
\end{tabular}


Table 1. Cont.

\begin{tabular}{|c|c|c|c|c|c|}
\hline Ways & Principles & Advantages & Disadvantages & Denitrifiers & Ref \\
\hline $\begin{array}{l}\text { Photocatalysis } \\
\text { denitrogena- } \\
\text { tion }\end{array}$ & $\begin{array}{l}\text { Most photocatalysts } \\
\text { are semiconductor } \\
\text { materials. Under light } \\
\text { radiation, oil } \\
\text { denitrogenation is } \\
\text { realized by the redox } \\
\text { of nitrides into } \\
\text { harmless small } \\
\text { molecules by } \\
\text { photogenerated } \\
\text { electrons and holes of } \\
\text { valence bands }\end{array}$ & $\begin{array}{l}\text { Safe, high stability, } \\
\text { high catalytic activity } \\
\text { and low energy } \\
\text { consumption }\end{array}$ & $\begin{array}{l}\text { Photogenerated charge } \\
\text { carriers need to } \\
\text { migrate to the } \\
\text { photocatalyst surface } \\
\text { and contact with the } \\
\text { adsorbed nitrides } \\
\text { before the redox } \\
\text { reaction occurs, but } \\
\text { their lifetime is only } \\
\text { nanosecond }\end{array}$ & $\begin{array}{l}\text { Visible light and } \\
\text { photocatalysts such } \\
\text { as nanocomposite } \\
\text { metal oxide catalysts }\end{array}$ & {$[21,22]$} \\
\hline $\begin{array}{l}\text { Microwave } \\
\text { denitrogena- } \\
\text { tion }\end{array}$ & $\begin{array}{l}\text { Non-thermal effect of } \\
\text { electromagnetic field } \\
\text { on reactive molecules }\end{array}$ & $\begin{array}{l}\text { Short reaction time, } \\
\text { high efficiency and } \\
\text { simple process }\end{array}$ & $\begin{array}{l}\text { Special equipment is } \\
\text { needed, and the } \\
\text { intensity, frequency, } \\
\text { modulation mode of } \\
\text { microwave and system } \\
\text { composition have } \\
\text { obvious impact on the } \\
\text { denitrogenation } \\
\text { results }\end{array}$ & $\begin{array}{l}\text { UHF } \\
\text { electromagnetic } \\
\text { wave in the range of } \\
0.1-100 \mathrm{~cm} \text { and } 300 \\
\mathrm{MHz}-300 \mathrm{GHz}\end{array}$ & [23] \\
\hline $\begin{array}{l}\text { Adsorption } \\
\text { denitrogena- } \\
\text { tion }\end{array}$ & $\begin{array}{l}\text { Solid adsorbents have } \\
\text { strong adsorption on } \\
\text { polar nitrogen } \\
\text { compounds }\end{array}$ & $\begin{array}{l}\text { Solid-liquid separation } \\
\text { is easier }\end{array}$ & $\begin{array}{l}\text { Multiple steps and } \\
\text { complex operation }\end{array}$ & $\begin{array}{l}\text { Chalk, silica gel, } \\
\text { resins, molecular } \\
\text { sieve, etc. }\end{array}$ & {$[24,25]$} \\
\hline $\begin{array}{l}\text { Biological deni- } \\
\text { trogenation }\end{array}$ & $\begin{array}{l}\text { The characteristic } \\
\text { catalytic ability of } \\
\text { microbial cultures or } \\
\text { their enzymes is used } \\
\text { to selectively remove } \\
\text { nitrogen compounds } \\
\text { from oils }\end{array}$ & $\begin{array}{l}\text { For high selectivity, } \\
\text { microorganisms have } \\
\text { no effect on } \\
\text { hydrocarbons in oil } \\
\text { products, and energy } \\
\text { consumption is low }\end{array}$ & $\begin{array}{l}\text { Process is slow; and } \\
\text { aldehydes, esters and } \\
\text { other substances in oil } \\
\text { products affect } \\
\text { microbial growth }\end{array}$ & $\begin{array}{l}\text { Various } \\
\text { microorganisms } \\
\text { such as nitroso } \\
\text { bacteria, } \\
\text { nitrobacteria, etc. }\end{array}$ & [26] \\
\hline
\end{tabular}

As new green solvents, ionic liquids are usually composed of large organic cations and small inorganic anions; their different combinations can result in different types and properties of ILs. Compared with conventional solvents, ionic liquids have many advantages, such as low vapor pressure, non-volatility, good thermal stability, low melting point, strong solubility, etc. Due to their flexible designability and tailored properties, they are used in various chemical and engineering fields, especially in different extraction and separation processes, as well as basic researches [27-29]. Huh et al. used 1-ethyl 3-methylimidazole ethyl bisulfate and zinc chloride ([EMIm] $\mathrm{EtSO}_{4}-\mathrm{ZnCl}_{2}$ ) to remove the impurities in diesel oil. The experimental results show that the combination of ionic liquid and zinc has an obvious removal effect on nitrides [30]. For the denitrogenation of indole as a neutral nitrogen compound, the extraction was mostly governed by the interaction between the anion of IL and the $\mathrm{H}$ atom of $\mathrm{N}-\mathrm{H}$, rather than by the coordination of indole to the $\mathrm{Zn}$ center. Besides, Chen et al. studied the removal of pyridine from simulated oil by the ionic liquid of $[\mathrm{Bmim}] \mathrm{Cl} / \mathrm{ZnCl}_{2}$ and the $\mathrm{N}$-content was undetectable after 2-stage extraction. Under the condition of $25^{\circ} \mathrm{C}$ and the ratio of IL to oil was 1:1, the removal efficiency of pyridine by the IL with $\mathrm{ZnCl}_{2}$ anion was $97.8 \%$ after $30 \mathrm{~min}$ [31]. In another case, Liu et al. extracted pyridine from simulated oil with three kinds of ionic liquids in the experiment. The results show that the pyridine extraction efficiency followed the order of $\left[\mathrm{C}_{4} \mathrm{C}_{1} \mathrm{im}\right]\left[\mathrm{NTf}_{2}\right](76.8 \mathrm{~mol} \%)>\left[\mathrm{C}_{4} \mathrm{C}_{1} \mathrm{im}\right][\mathrm{OTf}](72.5 \mathrm{~mol} \%)>\left[\mathrm{C}_{4} \mathrm{C}_{1} \mathrm{im}\right]\left[\mathrm{PF}_{6}\right](67.5 \mathrm{~mol} \%)>$ $\left[\mathrm{C}_{4} \mathrm{C}_{1} \mathrm{im}\right]\left[\mathrm{BF}_{4}\right](58.8 \mathrm{~mol} \%)$ [32]. When the cation was the same, it was found that the larger the anion was, the better the nitrogen removal effect of ILs was. Above research proves 
the feasibility of ionic liquids used in oil denitrogenation. However, there are only a few types of IL members used in individual investigation, and the nitrogen-containing object is relatively singular, so a lack of comparison exists. The separation kinetics are still unknown, which is not beneficial for mechanism exploration and process amplification. Besides that, the separation mode is only liquid-liquid biphasic extraction, which needs to be expanded in the current study.

Based on above background, quinolinium, 8-hydroxy-quinolinium, and benzothiazolium ionic liquids, containing the acidic anions of methanesulfonate $\left(\left[\mathrm{CH}_{3} \mathrm{SO}_{3}\right]^{-}\right)$, phosphate $\left(\left[\mathrm{H}_{2} \mathrm{PO}_{4}\right]^{-}\right)$, p-toluenesulfonate $\left([p-\mathrm{TSA}]^{-}\right)$, and bisulfate $\left(\left[\mathrm{HSO}_{4}\right]^{-}\right)$were synthesized. Then, the single stage extraction and 2-stage extraction were used in the extraction for the simulated oils containing pyridine, quinoline or aniline, and their mixture by using various IL solutions, respectively. Their denitrogenation performance was compared on the basis of structural features, and main extraction conditions were further investigated, including mass ratio of IL to water, mass ratio of IL to oil, and temperature. Furthermore, the extraction process was described by different kinetic equations. Recovery and reuse of IL were realized by back-extraction and liquid-liquid separation. Finally, based on the developed method for preparing adsorption tablets, corresponding immobilized IL was used to extract the target object in order to extend separation ways, which was more easily recovered after extraction.

\section{Material and Methods}

\subsection{Materials and Reagents}

All of the reagents and solvents used in the present study were of analytical-reagent grade or higher, which were used directly without special treatment unless otherwise specified. Benzothiazole, methanesulfonic acid, and aniline were purchased from TITAN Technology Co., Ltd. (Shanghai, China). Additionally, 8-hydroxyquinoline, quinoline, sulfuric acid, $p$-toluenesulfonic acid, phosphoric acid, ethanol, acetone, $n$-octane, ethyl cellulose, and pyridine are provided by Kelon Chemical Reagent Factory (Chengdu, China). All other unmentioned agents were purchased from Aladdin Chemical Reagent Company (Shanghai, China). Multi walled carbon nanotubes (length: 0.5-2 mm, diameter: 0-50 nm, $>95 \%$ ) were provided by XFNANO Materials Tech Co., Ltd. (Nanjing, China). Experimental water was ultrapure, which was obtained from the Milli-Q water purification system (Millipore, Bedford, MA, USA).

\subsection{Synthesis of ILS}

Twelve extractants with common cations and anions of ILs were prepared, and all of them have the melting points under $200{ }^{\circ} \mathrm{C}$. For convenience, they are uniformly called ILs in previous studies [33-35]. Related products, including quinolinium methanesulfonate ([Quli] $\left.\left[\mathrm{CH}_{3} \mathrm{SO}_{3}\right]\right)$, quinolinium phosphate ([Quli] $\left.\left[\mathrm{H}_{2} \mathrm{PO}_{4}\right]\right)$, quinolinium $p$-toluenesulfonate ([Quli][ $p$-TSA]), quinolinium bisulfate ([Quli][ $\left.\mathrm{HSO}_{4}\right]$ ), 8-hydroxyquinolinium methanesulfonate $\left([\mathrm{HHqu}]\left[\mathrm{CH}_{3} \mathrm{SO}_{3}\right]\right)$, 8-hydroxyquinolinium phosphate $\left([\mathrm{HHqu}]\left[\mathrm{H}_{2} \mathrm{PO}_{4}\right]\right)$, 8-hydroxyquinolinium $p$-toluenesulfonate ([HHqu][ $p$-TSA]), 8-hydroxyquinolinium bisulfate $\left([\mathrm{HHqu}]\left[\mathrm{HSO}_{4}\right]\right)$, benzothiazolium methanesulfonate $\left([\mathrm{HBth}]\left[\mathrm{CH}_{3} \mathrm{SO}_{3}\right]\right)$, benzothiazolium phosphate ([HBth][ $\left.\left.\mathrm{H}_{2} \mathrm{PO}_{4}\right]\right)$, benzothiazolium p-toluenesulfonate ([HBth][p-TSA]), and benzothiazolium bisulfate ([HBth] $\left[\mathrm{HSO}_{4}\right]$ ) were prepared for the comparative research. Other ionic liquids were purchased from ZhongkeKete technology industry Co., Ltd. (Lanzhou, China).

For four quinolinium ILs, their synthetic route was based on the developed way [33], and their yield was $69 \sim 83 \%$. Taking [Quli][ $\mathrm{HSO}_{4}$ ] as an example, $6.458 \mathrm{~g}(0.05 \mathrm{~mol})$ of quinoline was placed in a round bottom flask, and then $50 \mathrm{~mL}$ ethanol was added as solvent. The reaction was carried out under the condition of an ice bath, $4.92 \mathrm{~g}$ (slightly more than $0.05 \mathrm{~mol}$ ) of concentrated sulfuric acid was slowly added into the solution with a constant pressure titration funnel; the whole system was stirred magnetically at room temperature for $2 \mathrm{~h}$. After that, ethanol was removed, by rotary evaporation, to obtain a white solid 
product, which was washed with acetone several times. Finally, it was recrystallized in absolute ethanol and dried under vacuum for $24 \mathrm{~h}$.

For four benzothiazolium ILs, their synthetic route was based on the developed way [34], and their yield was $73 \% \sim 84 \%$. Taking [HBth] $\left[\mathrm{CH}_{3} \mathrm{SO}_{3}\right.$ ] as an example, $25 \mathrm{~mL}$ of $0.05 \mathrm{~mol}$ of benzothiazole aqueous solution was placed in the flask, and then $0.05 \mathrm{~mol}$ of methane sulfonic acid and $25 \mathrm{~mL}$ of anhydrous ethanol mixed solution were added, dropwisely, with a constant pressure titration funnel under ice bath conditions. The reaction was carried out by magnetic stirring at room temperature for $3 \mathrm{~h}$, and the solvent was removed, after the reaction, to obtain a white crude product. It was washed several times with ethyl acetate, then recrystallized in ethanol, and a white flake solid was obtained as the product after thorough dryness.

For four 8-hydroxyquinolinium ILs, their synthetic route was based on the developed way [35], and their yield was $66 \sim 79 \%$. Taking [HHqu][ $p$-TSA] as an example, $0.05 \mathrm{~mol}$ 8-hydroxyquinoline was mixed with $50 \mathrm{~mL}$ of absolute ethanol to form a homogeneous solution, and then, $25 \mathrm{~mL}$ anhydrous ethanol solution of $0.05 \mathrm{~mol} \mathrm{p}$-toluenesulfonic acid was slowly added to the solution with a constant pressure titration funnel under ice bath condition; the reaction was carried out by magnetic stirring at room temperature for $4 \mathrm{~h}$. After that, ethanol was removed by rotary evaporation to obtain a light yellow crude product. Then, it was washed with acetone for several times and recrystallized in ethanol. Finally, a yellow powder solid product was obtained after being dried in vacuum for $24 \mathrm{~h}$.

\subsection{Preparation of Simulated Oil for Separation}

According to the preparation of simulated oils and corresponding nitrogen content in current references [36], three kinds of simulated oils were obtained as follows:

(1) Preparation of quinoline simulated oil: $138.39 \mathrm{mg}$ of analytical pure quinoline was weighed and completely dissolved in $100 \mathrm{~mL}$ of $n$-octane by ultrasound assistance ( $300 \mathrm{~W}$ ) to prepare a solution. The concentration of quinoline was $1383.9 \mathrm{mg} / \mathrm{L}$ (the nitrogen content in the solution was $150 \mathrm{mg} / \mathrm{L}$ ).

(2) Preparation of aniline simulated oil: $99.64 \mathrm{mg}$ of analytical pure aniline was weighed and completely dissolved in $100 \mathrm{~mL}$ of $n$-octane by ultrasound assistance $(300 \mathrm{~W}$ ). The concentration of aniline was $996.4 \mathrm{mg} / \mathrm{L}$ (the nitrogen content in the solution was $150 \mathrm{mg} / \mathrm{L})$.

(3) Preparation of pyridine simulated oil: $84.64 \mathrm{mg}$ of analytical pure pyridine was weighed and completely dissolved in $100 \mathrm{~mL}$ of $n$-octane by ultrasound assistance $(300 \mathrm{~W})$. The concentration of pyridine was $846.4 \mathrm{mg} / \mathrm{L}$ (the nitrogen content in the solution was $150 \mathrm{mg} / \mathrm{L})$.

\subsection{Quantitative Analysis}

Quinoline, aniline and pyridine all have characteristic ultraviolet spectra, and their maximum absorbance wavelength is very different from that of those selected ILs, so ultraviolet visible (UV-Vis) spectrophotometry was used to determine the change of their concentration in the simulated oil before and after extraction to determine corresponding $\mathrm{N}$-removal efficiency. Here AOE380 UV spectrometer (Aoyi Instrument Co., Shanghai, China) was used for the following quantitation. For developing quantitative working curve, the oil samples with quinoline concentrations (x) of $6.92 \mathrm{mg} / \mathrm{L}, 13.84 \mathrm{mg} / \mathrm{L}, 27.70 \mathrm{mg} / \mathrm{L}$, $41.52 \mathrm{mg} / \mathrm{L}, 55.36 \mathrm{mg} / \mathrm{L}$, and $69.20 \mathrm{mg} / \mathrm{L}$ were prepared, respectively. Then, the absorbance (y) of quinoline in the oil was measured at the wavelength of $313 \mathrm{~nm}$ [37], and the standard curve was developed according to the relationship between absorbance (y) and the corresponding concentration $(\mathrm{x})$. As the result, the standard curve equation was obtained as $\mathrm{y}=0.0189 \mathrm{x}-0.0007, \mathrm{R}^{2}=0.9992$.

Similarly, the standard oil samples were prepared with the aniline concentrations (y) of $9.96 \mathrm{mg} / \mathrm{L}, 19.93 \mathrm{mg} / \mathrm{L}, 29.89 \mathrm{mg} / \mathrm{L}, 39.86 \mathrm{mg} / \mathrm{L}, 49.82 \mathrm{mg} / \mathrm{L}, 59.78 \mathrm{mg} / \mathrm{L}, 69.75 \mathrm{mg} / \mathrm{L}$, and $99.64 \mathrm{mg} / \mathrm{L}$, respectively. Then, the absorbance $(\mathrm{x})$ of aniline in the oil was measured at the wavelength of $280 \mathrm{~nm}$ [38], and its standard curve equation was developed as 
$y=0.0123 x-0.0258, R^{2}=0.9998$. Moreover, the standard oil samples were prepared with the pyridine concentrations (y) of $11.30 \mathrm{mg} / \mathrm{L}, 22.60 \mathrm{mg} / \mathrm{L}, 36.00 \mathrm{mg} / \mathrm{L}, 45.00 \mathrm{mg} / \mathrm{L}$, $56.50 \mathrm{mg} / \mathrm{L}, 71.00 \mathrm{mg} / \mathrm{L}, 85.00 \mathrm{mg} / \mathrm{L}, 98.00 \mathrm{mg} / \mathrm{L}$, and $113.00 \mathrm{mg} / \mathrm{L}$, respectively. Measure the absorbance (a) of pyridine in the solution at the wavelength of $270 \mathrm{~nm}$ [39], and its standard curve equation was developed, as $y=0.002371 x-0.0167, R^{2}=0.9997$. These correlation coefficients proved the good linear relationship between concentration and UV absorbance. All experimental values were obtained from three parallel experiments.

\subsection{Denitrogenation Experiments}

A certain concentration of ionic liquid aqueous solution and simulated oil were added in a $50 \mathrm{~mL}$ conical flask and oscillated at a certain temperature for a period of time. After reaching the extraction end, the whole system stood for $30 \mathrm{~min}$, and the upper simulated oil was sampled and analyzed by using the above spectroscopic way, together with working curves, to determine the concentration of quinoline, aniline and pyridine in the simulated oil after the removal of ionic liquid. Their initial concentration was $\mathrm{N}_{0}(\mathrm{mg} / \mathrm{L})$ and residual concentration was quantified as $\mathrm{N}(\mathrm{mg} / \mathrm{L})$, and related denitrogenation efficiency could be calculated according to the following equation:

$$
\text { N-removal efficiency }(E)=\left(\mathrm{N}_{0}-\mathrm{N}\right) / \mathrm{N}_{0} \times 100 \%
$$

\section{Results}

\subsection{Identification of Synthesized ILs}

Here, 8-hydroxyquinolinium bisulfate ([HHqu] $\left.\left[\mathrm{HSO}_{4}\right]\right)$ and benzothiazolium bisulfate ([HBth] $\left.\left[\mathrm{HSO}_{4}\right]\right)$ are taken as two representatives for spectral analysis, which were the potential ideal extractants for target nitrogen compounds. Firstly, characterization of 8-hydroxyquinoline bisulfate ([HHqu[ $\left.\left[\mathrm{HSO}_{4}\right]\right)$ and benzothiazole bisulfate ([HBth $\left.\left[\mathrm{HSO}_{4}\right]\right)$ with infrared spectra was performed, which are shown in Figure 1. Obviously, the broad peak, with a wavenumber of nearly $3400 \mathrm{~cm}^{-1}$, is formed by the stretching vibration of $-\mathrm{OH}$, and the two peaks with wave number of $1600 \mathrm{~cm}^{-1}$ and $1550 \mathrm{~cm}^{-1}$ are mainly ascribed to the skeleton vibration of an aromatic ring. Besides that, the $\mathrm{O}=\mathrm{S}=\mathrm{O}$ asymmetric and symmetric stretching vibration peaks of $\mathrm{HSO}_{4}{ }^{-}$anion appeared at about $1200 \mathrm{~cm}^{-1}$ and $570 \mathrm{~cm}^{-1}$. In detail, the signal assignment of related absorbance peaks and typical groups is summarized in Table 2.
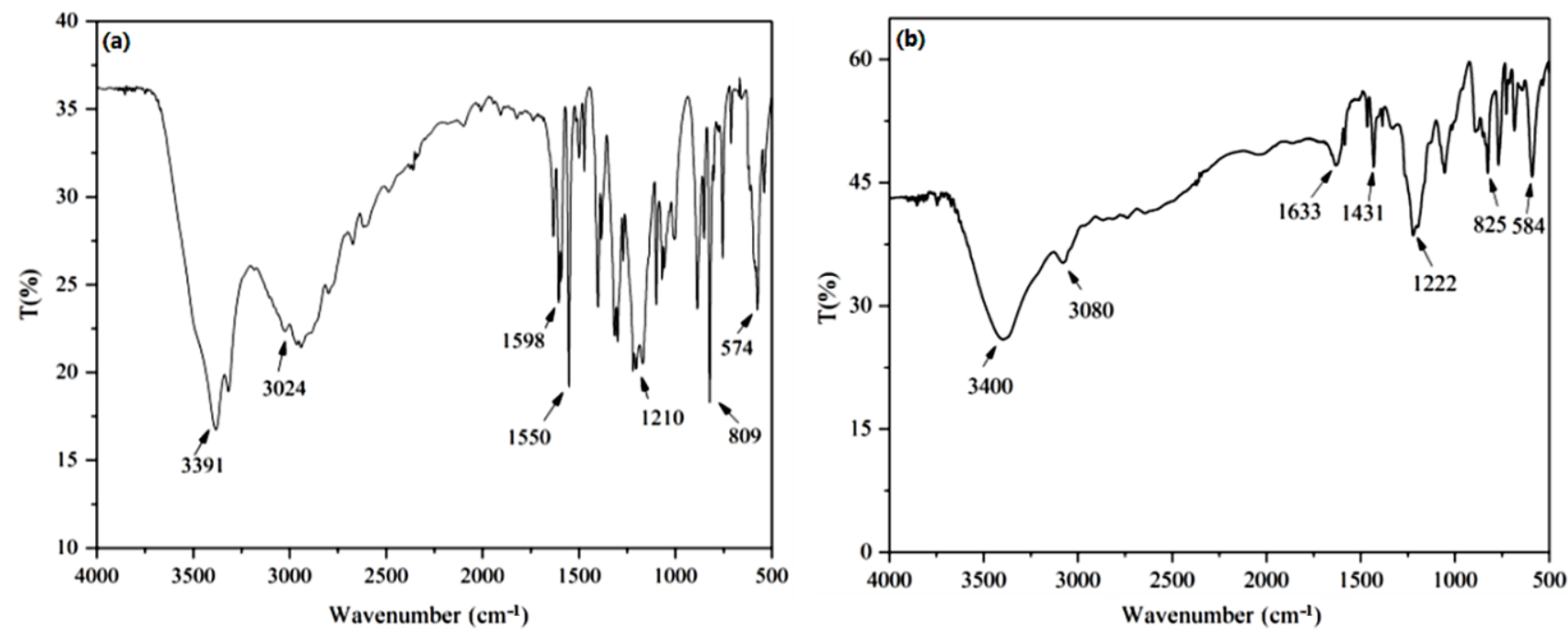

Figure 1. The IR spectra of $[\mathrm{HHqu}]\left[\mathrm{HSO}_{4}\right](\mathbf{a})$ and $[\mathrm{HBth}]\left[\mathrm{HSO}_{4}\right](\mathbf{b})$. 
Table 2. FI-IR spectra analysis of $[\mathrm{HHqu}]\left[\mathrm{HSO}_{4}\right]$ and $[\mathrm{HBth}]\left[\mathrm{HSO}_{4}\right]$.

\begin{tabular}{|c|c|c|c|c|c|}
\hline \multicolumn{3}{|c|}{$[\mathrm{HHqu}]\left[\mathrm{HSO}_{4}\right]$} & \multicolumn{3}{|c|}{$[\mathrm{HBth}]\left[\mathrm{HSO}_{4}\right]$} \\
\hline Group & Wavenumber & Vibration & Group & Wavenumber & Vibration \\
\hline$-\mathrm{OH}$ & 3391 & $v_{\mathrm{O}-\mathrm{H}}$ & $-\mathrm{OH}$ & 3400 & $v_{\mathrm{O}-\mathrm{H}}$ \\
\hline$=\mathrm{CH}$ & 3024 & $v_{=} \mathrm{CH}$ & $=\mathrm{CH}$ & 3080 & $v=\mathrm{CH}$ \\
\hline $\mathrm{C}=\mathrm{C}$ & 1598,1550 & $v_{C=C}$ & $\mathrm{C}=\mathrm{C}$ & 1633,1584 & $v_{C=C}$ \\
\hline $\mathrm{C}-\mathrm{N}$ & 1390 & $v_{\mathrm{C}-\mathrm{N}}$ & $\mathrm{C}-\mathrm{N}$ & 1431 & $v_{\mathrm{C}-\mathrm{N}}$ \\
\hline $\mathrm{S}=\mathrm{O}$ & 1210,574 & $\begin{array}{l}v_{\text {as } S}=\mathrm{O} \\
v_{\mathrm{S} S}=\mathrm{O}\end{array}$ & $\mathrm{S}=\mathrm{O}$ & 1222,584 & $\begin{array}{l}v_{\text {as } S}=\mathrm{O} \\
v_{\mathrm{S} S}=\mathrm{O}\end{array}$ \\
\hline$=\mathrm{CH}$ & 809 & $\gamma=\mathrm{CH}$ & $=\mathrm{CH}$ & 825 & $\gamma=\mathrm{CH}$ \\
\hline
\end{tabular}

Furthermore, the two ILs of $[\mathrm{HHqu}]\left[\mathrm{HSO}_{4}\right]$ and $[\mathrm{HBth}]\left[\mathrm{HSO}_{4}\right]$ were characterized by ${ }^{1} \mathrm{H}$ NMR (500 MHz, MeOD), and their hydrogen atoms were numbered, respectively. The spectra are shown in Figure 2, and the NMR data are included as: $8.91(\mathrm{H}-1), 8.85$ (H-2), $8.89(\mathrm{H}-3), 7.63(\mathrm{H}-4), 7.88(\mathrm{H}-5), 7.90(\mathrm{H}-6)$ for $[\mathrm{HHqu}]\left[\mathrm{HSO}_{4}\right] ; 9.74(\mathrm{H}-1), 8.80(\mathrm{H}-2)$, $7.59(\mathrm{H}-3), 7.61(\mathrm{H}-4), 7.68(\mathrm{H}-5)$ for $\left.[\mathrm{HBth}] \mathrm{HSO}_{4}\right]$. Every signal appears except active protons on $\mathrm{O}$ or $\mathrm{N}$ atom for the use of MeOD as solvent, and corresponding signals are clearly separated. The whole information of the two ILs have been compared with those in references [33-35], and it can be proved that the synthesized products are target ionic liquids, according to spectral analysis.
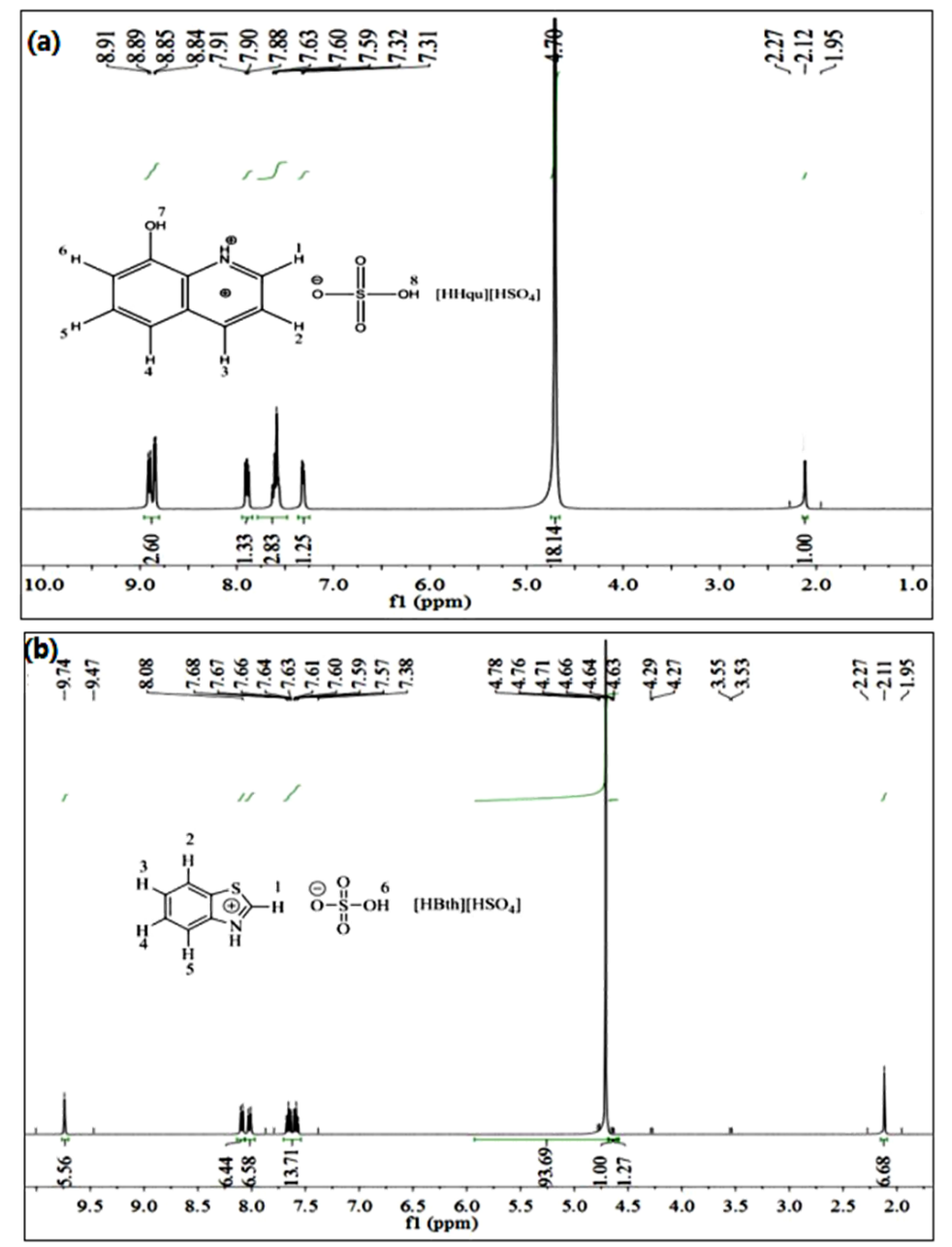

Figure 2. ${ }^{1} \mathrm{H} \mathrm{NMR}$ of $[\mathrm{HHqu}]\left[\mathrm{HSO}_{4}\right]$ (a) and $[\mathrm{HBth}]\left[\mathrm{HSO}_{4}\right]$ (b) $(500 \mathrm{MHz}, \mathrm{MeOD})$. 


\subsection{Comparison among ILs}

Larger cations can offer more surface area for absorption through van der Waals interactions with targets [32], so quinolinium, 8-hydroxyquinolinium, and benzothiazolium cations were selected, instead of the most common imidazole, in this study. According to previous findings [40], acidic anions of ILs play very significant role in oil denitrogenation for related $\mathrm{N}$-compounds, so the three kinds of cations were combined with them for comprehensive screening. In addition, considering the preparation cost, stability, and commonality, some reported ILs are not compared here. In this section, $0.25 \mathrm{~g}$ of twelve kinds of ionic liquids and $2 \mathrm{~mL}$ of water were added respectively into a $50 \mathrm{~mL}$ conical flask, and then they were mixed with $2.5 \mathrm{~g}$ of simulated oil containing pyridine, quinoline, or aniline. After constant temperature oscillation at $200 \mathrm{rpm}$ and $30{ }^{\circ} \mathrm{C}$ for $30 \mathrm{~min}$, and standing for $30 \mathrm{~min}$, the sample of upper oil phase was taken to measure its UV absorbance; then, the concentration of related compound and denitrogenation efficiency of ILs were calculated for comparison. The experimental results are shown in Figure 3. Besides that, the volume of ionic liquid phase (water phase) and oil phase was observed during the whole process. As the result, no significant change occurred, suggesting that there was no obvious mutual solubility between the two phases.

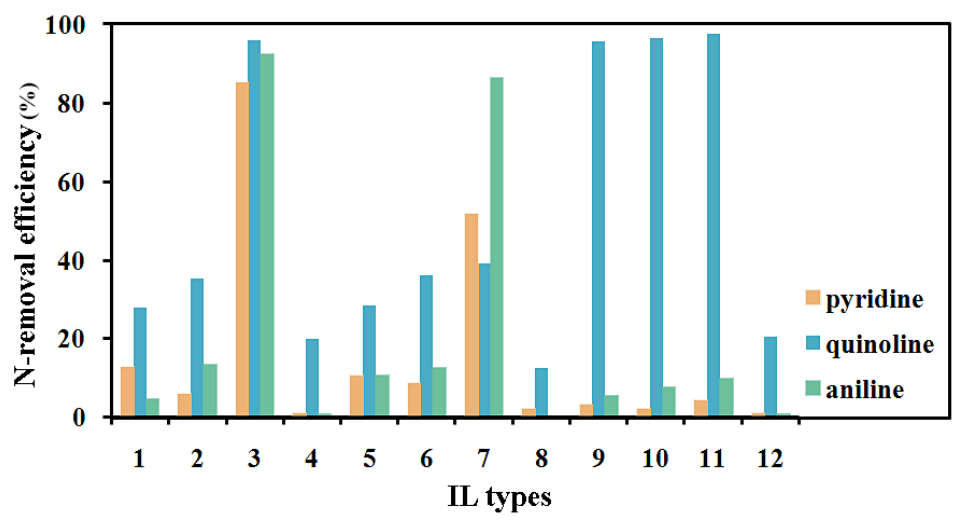

Figure 3. N-removal efficiency of twelve ILs (1: [HHqu][p-TSA], 2: [HHqu][ $\left.\mathrm{CH}_{3} \mathrm{SO}_{3}\right]$, 3: [HHqu][ $\left.\mathrm{HSO}_{4}\right], 4:[\mathrm{HHqu}]\left[\mathrm{H}_{2} \mathrm{PO}_{4}\right]$, 5: [Quli][ $p$-TSA]; 6: [Quli][ $\left.\mathrm{CH}_{3} \mathrm{SO}_{3}\right]$; 7: [Quli]][ $\left.\mathrm{HSO}_{4}\right]$; 8: [Quli][ $\left.\mathrm{H}_{2} \mathrm{PO}_{4}\right]$; 9: [HBth][p-TSA]; 10: [HBth] $\left[\mathrm{CH}_{3} \mathrm{SO}_{3}\right] ; 11$ : [HBth][$\left[\mathrm{HSO}_{4}\right] ; 12:$ [HBth] $\left.\left[\mathrm{H}_{2} \mathrm{PO}_{4}\right]\right)$.

\subsubsection{Removal of Pyridine from Simulated Oil}

It can be seen that the removal capacity of pyridine simulated oil by ionic liquids with different anions with the same cationic structure is in the order of $\mathrm{HSO}_{4}{ }^{-}>p-\mathrm{TSA}^{-}>$ $\mathrm{CH}_{3} \mathrm{SO}_{3}{ }^{-}>\mathrm{H}_{2} \mathrm{PO}_{4}{ }^{-}$, indicating that the stronger the acidity, the better the removal effect of pyridine. When the anions of ionic liquids are the same, 8-hydroxyquinoline bisulfate shows the best $\mathrm{N}$-removal performance $(85.6 \%)$, followed by quinoline bisulfate $(51.9 \%)$ and 8 -hydroxyquinoline tosilate $(12.7 \%)$. Their performance is significantly different, and the removal effect of more than half of tested ILs is not obvious. For the difference between $[\mathrm{HHqu}]\left[\mathrm{HSO}_{4}\right]$ and [Quli] $\left[\mathrm{HSO}_{4}\right]$, the reason can be ascribed to the fact 8-hydroxyquinoline based cation contains an extra hydroxyl group, which can provide H-bonding effect; besides, the hydroxyl group is connected with the benzene ring and activates the latter, making its denitrogenation efficiency higher. Moreover, for comparison with reported data [41], the N-removal efficiency of four ILs including 1-butyl-3-methylimdazolium dicyanamide, 1-ethyl-3-methylimdazolium dicyanamide, ethylated tetrahydrothiophenium dicyanamide, and tetrahedral ethyldimethylsulfonium dicyanamide for pyridine-containing oil was $72.7 \%, 69.1 \%, 63.5 \%$, and $59.8 \%$, respectively; the extractive performance of [HHQu][HSO $\left.\mathrm{HS}_{4}\right]$ is competitive. Therefore, it was selected as the ionic liquid for removing pyridine from simulated oil. 


\subsubsection{Removal of Quinoline from Simulated Oil}

As a whole, the removal efficiency of tested ILs for quinoline is obviously higher than that for the other two objects except [Quli][HSO4], and there are four ILs above $90 \%$ ([HHqu][$\left[\mathrm{HSO}_{4}\right]$ ]: $96.3 \%$, [HBth][ $p$-TSA]: $96.1 \%$, [HBth] $\left[\mathrm{CH}_{3} \mathrm{SO}_{3}\right.$ ]: $96.9 \%$ and [HBth][HSO ${ }_{4}$ ]: $97.8 \%$ ). A little differently, the removal performance of quinoline from simulated oil by ionic liquids with different anions with the same cationic structure is in the order of $\mathrm{HSO}_{4}{ }^{-}>\mathrm{CH}_{3} \mathrm{SO}_{3}{ }^{-}>p$ - $\mathrm{TSA}^{-}>\mathrm{H}_{2} \mathrm{PO}_{4}{ }^{-}$. It shows that the stronger the acidity, the better the removal effect of ILs for quinoline. Among 8-hydroxyquinoline, quinoline, and benzothiazole ionic liquids, the last type exhibits the best performance on the removal of quinoline and great superiority over the other two. Furthermore, it can be found the benzothiazolium series has high selectivity for quinoline, according to the comparison of the column height of three objects. Considering the combination of $\mathrm{H}_{2} \mathrm{PO}_{4}{ }^{-}$and the cation of 1-butyl-3-methylimidazolium ([Bmim]) has achieved more than $99 \% \mathrm{~N}$-removal efficiency of quinoline in its $n$-heptane solution (the nitrogen content in the solution was also $150 \mathrm{mg} / \mathrm{L}$ ) in the previous study [36], the performance of $[\mathrm{Bmim}]\left[\mathrm{H}_{2} \mathrm{PO}_{4}\right]$ was investigated in an additional experiment under the same conditions as above, and its N-removal efficiency was finally determined as $97.0 \%$. Therefore, benzothiazole bisulfate [HBth][HSO $\left.\mathrm{H}_{4}\right]$ was selected as the ionic liquid for removing quinoline from simulated oil.

\subsubsection{Removal of Aniline from Simulated Oil}

Generally, the basic order is pyridine $>$ quinoline $>$ aniline. For the removal of aniline, [HHqu][ $\left.\mathrm{HSO}_{4}\right](92.7 \%)$ also shows the best performance among twelve ILs as for the removal of pyridine, followed by [Quli][HSO 4 ] $(86.7 \%)$. It can be seen from, the comparison in Figure 3, that the removal efficiency of aniline from simulated oil by ionic liquids, with different anions but the same cation, is in the order of $\mathrm{HSO}_{4}{ }^{-}>\mathrm{CH}_{3} \mathrm{SO}_{3}{ }^{-}>p-\mathrm{TSA}^{-}>\mathrm{H}_{2} \mathrm{PO}_{4}{ }^{-}$too. Similarly, it proves that the stronger the acidity of anions, the better the removal effect of aniline. Moreover, dihydrogen phosphate shows the worst performance not only in the four anions for aniline but also in the extraction of three objects combined with different cations (only $0.40 \sim 0.51 \%$ for aniline, compared with $0.74 \sim 1.80 \%$ for pyridine, $10.5 \sim 20.4 \%$ for quinoline). As for the cations, none of the four benzothiazolium ionic liquids had a removal efficiency of higher than $10 \%$, which do not seem to be ideal choices for aniline.

\section{Discussions}

\subsection{Separation Conditions}

\subsubsection{Mass Ratio of IL to Deionized Water}

$0.25 \mathrm{~g}$ of the best IL ([HHqu][ $\left.\mathrm{HSO}_{4}\right]$ for pyridine and aniline, and $[\mathrm{HBth}]\left[\mathrm{HSO}_{4}\right]$ for quinoline) was added into five $50 \mathrm{~mL}$ conical flasks, then $0 \sim 2.5 \mathrm{~g}$ of deionized water was mixed with the IL in the flasks, respectively. After that, $2.5 \mathrm{~g}$ of simulated oil, containing pyridine, quinoline, or aniline, was added in the system, which was shaken and reached equilibrium at $250 \mathrm{rpm}$ and $30{ }^{\circ} \mathrm{C}$. After standing for $30 \mathrm{~min}$, the sample of upper oil phase was taken out to measure its UV absorbance, and denitrogenation efficiency was obtained according to the calculation. Figure 4 shows the results for the effect of $\mathrm{IL}-\mathrm{H}_{2} \mathrm{O}$ ratio $(w / w, \mathrm{~g} / \mathrm{g})$ on the $\mathrm{N}$-removal efficiency. Obviously, it can be found that the highest removal efficiency of all the three target components is reached when the mass-volume ratio of IL to water is 1:1; at this point, the removal efficiency of pyridine, quinoline, and aniline is $99.61 \%, 99.04 \%$, and $97.21 \%$, respectively. In addition, the overall trend in Figure $4 \mathrm{a}-\mathrm{c}$ is similar. With the increase in water, the denitrogenation effect of different ionic liquids increases first and then decreases. When the dosage of water becomes greater, the concentration of ionic liquid will decrease, and the acidity of the system weakens, resulting in the reduction in N-removal capacity. On the contrary, the high viscosity of IL phase is not conducive to mass transfer in the extraction process if water is absent or too little. Compared with the mass ratio of $[\mathrm{Bmim}] \mathrm{H}_{2} \mathrm{PO}_{4}$ and $[\mathrm{PSmim}] \mathrm{H}_{2} \mathrm{PO}_{4} / \mathrm{H}_{2} \mathrm{O}$ (1:0.5) to remove quinoline from the simulated oil $(150 \mathrm{mg} / \mathrm{L})$ [36], the mass ratio of 1:1 
indicates the less consumption of IL and higher efficiency in this study. According to the experimental results, the mass ratio of IL to water was set at 1:1 for the subsequent removal of pyridine, quinoline, and aniline.
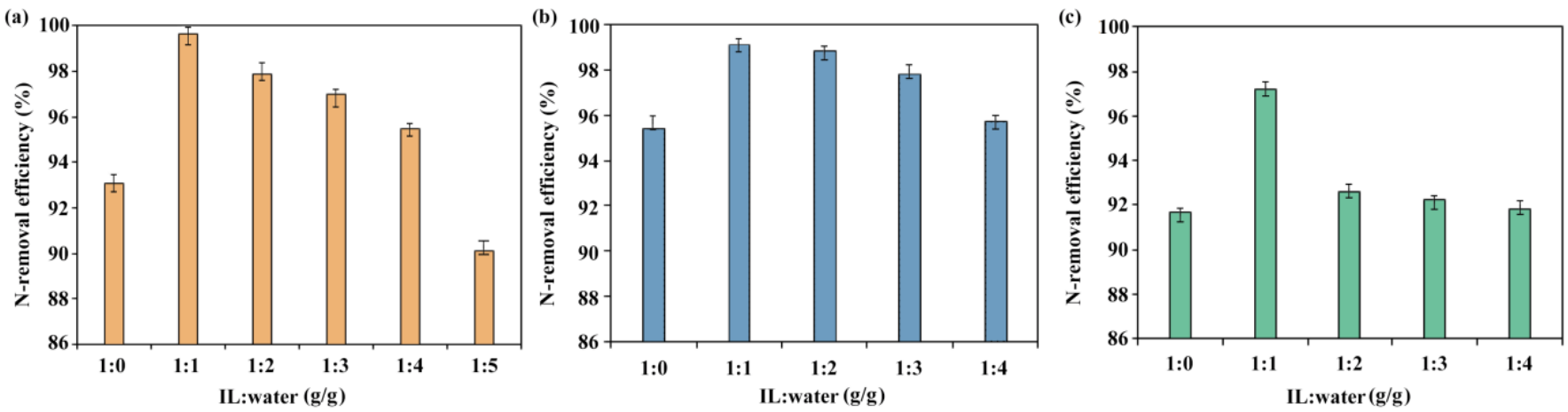

Figure 4. N-removal efficiency of the best IL with different mass ratio to water for (a) pyridine, (b) quinoline, and (c) aniline.

\subsubsection{Mass Ratio of IL to Oil}

In this section, $0.25 \mathrm{~g}$ of the selected IL and $0.25 \mathrm{~g}$ of water were first placed in the $50 \mathrm{~mL}$ conical flask, and then, $1.5 \mathrm{~g}$ (IL:oil = 1:6, $w / w) \sim 15 \mathrm{~g}$ (IL:oil = 1:60, $w / w)$ of simulated oil containing pyridine, quinoline, or aniline was added in the system, respectively. After shaking at $250 \mathrm{rpm}$ on $30^{\circ} \mathrm{C}$, the equilibrium was reached. After standing for $30 \mathrm{~min}$, the sample of oil phase was taken to measure its UV absorbance, and the denitrogenation efficiency was determined. The experimental results are shown in Figure 5. The results indicate that the removal efficiency of pyridine in simulated oil gradually decreases with the decrease in mass-mass ratio of IL to oil. When the ratio is 1:10, the denitrogenation efficiency reaches $98.77 \%$, and when the mass-mass ratio of $[\mathrm{HHqu}]\left[\mathrm{HSO}_{4}\right]$ to oil becomes $1: 60$, the efficiency of pyridine removal turns to $96.01 \%$. In other words, when the processing amount of oil is expanded six times, the IL performance is only reduced by $2.76 \%$; this shows the strong removal capacity of this method. Similarly, benzothiazole bisulfate also has a high extraction effect for quinoline in the simulated oil. When the mass-mass ratio of $[\mathrm{HBth}]\left[\mathrm{HSO}_{4}\right]$ to oil is changed from 1:10 to 1:80, the denitrogenation efficiency is only reduced from $99.49 \%$ to $96.65 \%$, and when the agent oil ratio is 1:60, the removal efficiency of quinoline is $98.95 \%$. With the gradual decrease in $[\mathrm{HHqu}]\left[\mathrm{HSO}_{4}\right]$-oil mass ratio from 1:10 to 1:70, the removal effect of aniline also showed an obvious downward trend, and the denitrogenation efficiency decreased from $97.21 \%$ to $93.66 \%$. At all experimental points, the removal efficiency of the three objective substances are higher than $90 \%$, which provides a great space for the operator to choose conditions for treating different amounts of oil. In reported ways, 1:1 of IL to oil is very common [37,42], which results in much higher consumption of IL and lower economic efficiency. Moreover, as another kind of green medium, the deep eutectic solvents (DESs), composed of urea and a series of acids (i.e., citric acid/oxalic acid/malonic acid/ $p$-toluenesulfonic acid), were applied to extract $\mathrm{N}$-compounds with the mass ratio of 1:2 to oil recently [43], and here, the consumption of IL in the ratio of 1:10 is much lower than that of DESs, indicating the strong N-removal capacity of related ILs in this study.

\subsubsection{Temperature}

Next, $0.25 \mathrm{~g}$ of the selected IL, and $0.25 \mathrm{~g}$ of water, were mixed in a $50 \mathrm{~mL}$ conical flask, and $10 \mathrm{~g}$ of simulated oil containing pyridine, quinoline, or aniline was added into the system at $250 \mathrm{rpm}$. After constant temperature oscillation on $25^{\circ} \mathrm{C}, 30^{\circ} \mathrm{C}, 40^{\circ} \mathrm{C}, 50^{\circ} \mathrm{C}$, or $60^{\circ} \mathrm{C}$ for $20 \mathrm{~min}$ and standing for $30 \mathrm{~min}$, the upper oil was sampled for measurement of its UV absorbance, and the denitrogenation efficiency was obtained after calculation. The experimental results are shown in Figure 6. It can be seen that, when the temperature is increased from $25^{\circ} \mathrm{C}$ to $60^{\circ} \mathrm{C}$, the efficiency of pyridine removal will decrease from 
$98.90 \%$ to $87.20 \%$, and the denitrogenation result reaches the best level at room temperature. The reason is that the removal of basic nitrogenous compounds by ionic liquids is an exothermic process, and higher temperature is not conducive to the progress of separation, so the denitrogenation efficiency decreases, obviously. Similarly, if the temperature rises from $25{ }^{\circ} \mathrm{C}$ to $60{ }^{\circ} \mathrm{C}$, the efficiency of removing quinoline or aniline was reduced from $99.05 \%$ to $95.29 \%$ or from $97.61 \%$ to $93.33 \%$, respectively. By comparison, the effect of temperature on pyridine removal is the most significant. Therefore, room temperature $\left(25^{\circ} \mathrm{C}\right)$ was selected for this experiment as the appropriate temperature for removing the three components. It is desirable for large scale applications since it guarantees extraction at, or below, ambient conditions, thus consuming less energy. For comparison, $50{ }^{\circ} \mathrm{C}$ was used in the reported method by using $\mathrm{CH}_{3} \mathrm{CONH}_{2}-0.3 \mathrm{ZnCl}_{2}$ as the extractant [44].
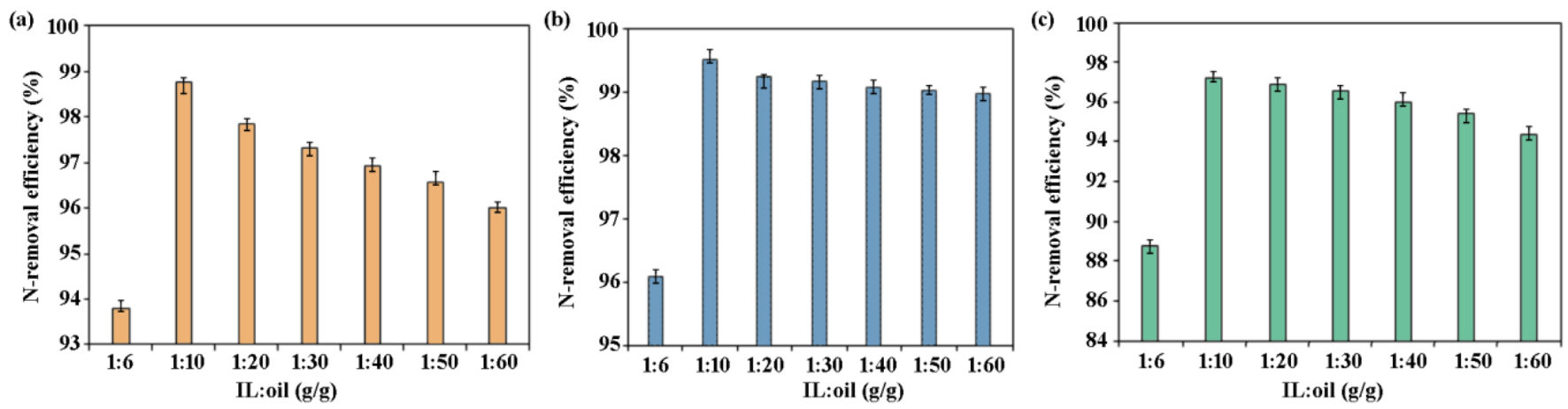

Figure 5. N-removal efficiency of the best IL with different mass ratio of IL to oil for (a) pyridine, (b) quinoline, (c) aniline.
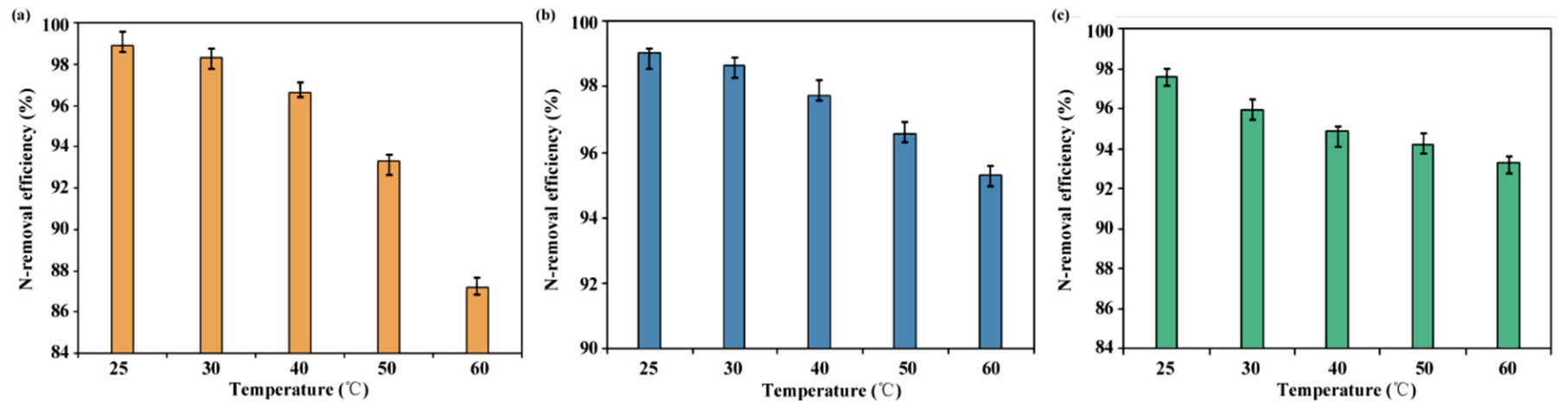

Figure 6. N-removal efficiency of the best IL under different temperatures for (a) pyridine, (b) quinoline, (c) aniline.

\subsubsection{Oscillation Speed}

Relatively, oscillation speed is not a very significant parameter, as it was above. Low speed can result in the unsatisfied efficiency of mass transfer during extraction, while excessive speed will be unnecessary and even cause severe emulsification together with difficult phase separation. According to current reports and pilot experiments, the effect of three levels of oscillation speed (low: 200, medium: 250, high: $300 \mathrm{rpm}$ ) on N-removal efficiency was explored under the same conditions $(0.25 \mathrm{~g} \mathrm{IL}, 0.25 \mathrm{~g}$ water, $10 \mathrm{~g}$ simulated oil, $25^{\circ} \mathrm{C}$ and $20 \mathrm{~min}$ ). The results in Figure 7 indicate the improvement is not obvious when the oscillation speed reaches $300 \mathrm{rpm}$. In order to reduce the power consumption and standing time, $250 \mathrm{rpm}$ was chosen at last, which was much lower than $1000 \mathrm{rpm}$ in previous processes [32]. At this level, ideal N-removal results for three kinds of oil samples can be obtained, and the two phases, composed of oil and IL-water, can be separated naturally. 


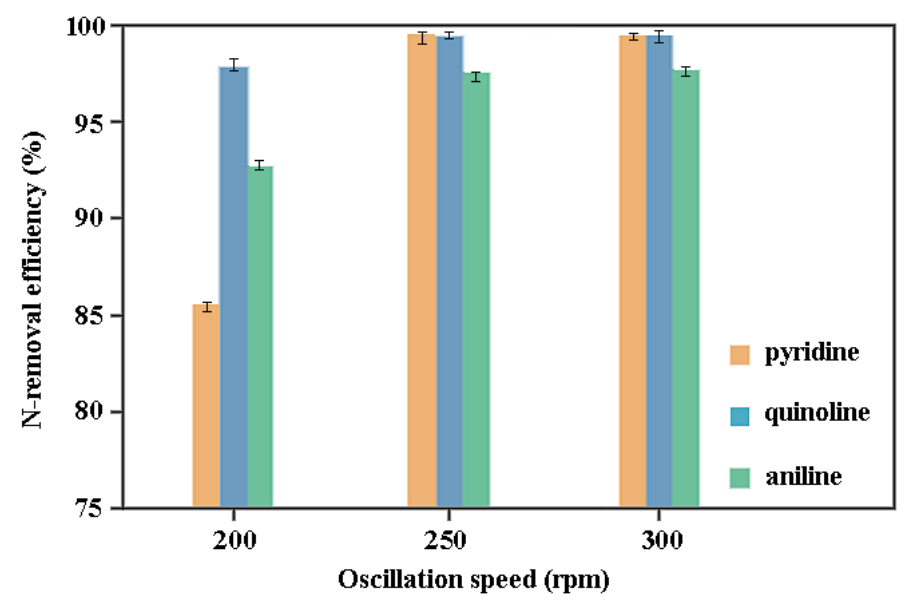

Figure 7. N-removal efficiency of the best IL with different oscillation speeds for pyridine, quinoline, and aniline.

\subsection{Separation Kinetics}

The study of extraction kinetics can make us understand the separation process more deeply. In some cases, extraction kinetics are a function of chemical reaction speed and diffusion speed; the chemical reaction can include bond destruction and formation, molecular polymerization or intermediation, and the reaction may occur in the phase or at the interface. These have an impact on the dynamic process. At the same time, the mass transfer of the diffusion process has a more complex effect on the kinetic process. For further analysis of related separation stages and mechanism, a kinetic study was carried out to explore the extraction process. Firstly, it was found the extraction speed of quinoline by $[\mathrm{HBth}]\left[\mathrm{HSO}_{4}\right]$ was higher than that of pyridine or aniline by $[\mathrm{HHqu}]\left[\mathrm{HSO}_{4}\right]$. For the former, its concentration in oil remained unchanged after $10 \mathrm{~min}$; for the latter two, their concentration in oil would not decrease after $20 \mathrm{~min}$. Compared with the N-removal duration of $[\mathrm{Bmim}] \mathrm{H}_{2} \mathrm{PO}_{4}$ and $\left[\mathrm{PSmim}_{3} \mathrm{H}_{2} \mathrm{PO}_{4}(30 \mathrm{~min})\right.$ [36], the time needed to reach extraction equilibrium is reduced by $1 / 3$ to $2 / 3$ in this study. Furthermore, the mass transfer process was described by pseudo-first and second order models, successively. The pseudo-first order model can be expressed according to [45] as:

$$
\ln \left(C_{s}-C_{t}\right)=-k_{1} t+\ln \left(C_{s}-C_{0}\right)
$$

where $k_{1}$ is the first-order kinetic constant; $C_{S}$ is the reduced concentration of the $N$ compound in oil phase at extraction equilibrium; $C_{t}$ is its reduced concentration in the oil phase at time $t ; C_{0}$ is its initial concentration in the oil phase.

In addition, the pseudo-second order model can be expressed according to [46] as:

$$
\frac{t}{C_{t}}=\frac{1}{k_{2} C_{s}^{2}}+\frac{t}{C_{s}}
$$

where $k_{2}$ is the second-order kinetic constant; $C_{S}$ is the reduced concentration of the $N$ compound in oil phase at extraction equilibrium; $C_{t}$ is its reduced concentration in the oil phase at time $t$.

Generally, the first-order kinetic model shows that the extraction efficiency is directly proportional to the target concentration, and the initial concentration has no effect on the time to reach certain extraction efficiency. For the second-order kinetic model, the extraction efficiency is directly proportional to the square of the concentration, and the extraction speed is related to the initial concentration of the object. As shown in Table 3, the values of $R^{2}$ in a pseudo-first model are obviously higher than those in a pseudo-second model, indicating the kinetic data can be better fitted by the former. Compared with similar extraction process of other objects with ILs, the pseudo-first model is also more common than other models. 
Table 3. The fitting results of pseudo-first order and pseudo-second order models for three objects.

\begin{tabular}{|c|c|c|c|c|c|c|}
\hline \multirow[b]{2}{*}{ Object } & \multicolumn{3}{|c|}{ Pseudo-First Model } & \multicolumn{3}{|c|}{ Pseudo-Second Model } \\
\hline & $\begin{array}{c}\text { Fitted } \\
\text { Equation }\end{array}$ & $k_{1}(1 / \mathrm{min})$ & $\mathbf{R}^{2}$ & $\begin{array}{c}\text { Fitted } \\
\text { Equation }\end{array}$ & $\begin{array}{c}k_{2} \\
(\mathrm{~L} / \mathrm{mg} \cdot \mathrm{min})\end{array}$ & $\mathbf{R}^{2}$ \\
\hline Pyridine & $\begin{array}{c}y=-0.20 x \\
-2.58\end{array}$ & 0.20 & 0.996 & $\begin{array}{c}y=58.28 x \\
+407.59\end{array}$ & 8.33 & 0.970 \\
\hline Quinoline & $\begin{array}{c}y=-0.35 x \\
-4.02\end{array}$ & 0.35 & 0.994 & $\begin{array}{c}y=58.99 x \\
+254.55\end{array}$ & 14.17 & 0.974 \\
\hline Aniline & $\begin{array}{c}y=-0.19 x \\
-3.45\end{array}$ & 0.19 & 0.991 & $\begin{array}{c}y=56.11 x \\
+418.70\end{array}$ & 7.52 & 0.966 \\
\hline
\end{tabular}

\subsection{Denitrogenation of the Mixed Simulated Oils by ILs in Two-Step Extraction}

Considering that an actual oil sample generally contains various nitrides at the same time, it is necessary to investigate the denitrogenation effect of ionic liquids on simulated oil under the coexistence of three target components in this section. Firstly, the three simulated oils were mixed according to the volume ratio of 1:1:1. Therefore, the nitrogen content of the mixed simulated oil was still kept as $150 \mathrm{mg} / \mathrm{L}$, and pyridine, quinoline, and aniline coexisted in the oil. Secondly, a two-step extraction method was established here, that is, the aqueous solutions of two ionic liquids of $[\mathrm{HBth}]\left[\mathrm{HSO}_{4}\right]$ and $[\mathrm{HHqu}]\left[\mathrm{HSO}_{4}\right]$ were firstly prepared according to the ratio of 1:1 (IL/water, $\mathrm{g} / \mathrm{mL})$. Then, the extractant of $[\mathrm{HHqu}]\left[\mathrm{HSO}_{4}\right]$ solution was mixed with the oil phase, according to the mass ratio of ionic liquid to oil 1:10 (g/g); after extraction at $25^{\circ} \mathrm{C}$ for $20 \mathrm{~min}$, biphase separation was carried out with a separating funnel. Then, the $[\mathrm{HBth}]\left[\mathrm{HSO}_{4}\right]$ aqueous solution was mixed with the oil phase for secondary extraction. Similarly, the N-removal efficiency of the three objects was determined by measuring their final residual concentration in the oil phase. As the result, the removal efficiency of pyridine, quinoline, and aniline was determined as $99.03 \%, 98.86 \%$, and $97.58 \%$, respectively. If the $[\mathrm{HBth}]\left[\mathrm{HSO}_{4}\right]$ aqueous solution was used before $[\mathrm{HHqu}]\left[\mathrm{HSO}_{4}\right]$ solution, the removal efficiency of pyridine, quinoline, and aniline became $98.97 \%, 98.82 \%$, and $97.50 \%$, respectively. In summary, it can be found that there is no obvious difference between two kinds of extraction sequences, and two ILs can also perform when facing the samples of single simulated oil.

\subsection{IL Recovery and Reuse Performance}

In previous studies, ionic liquids could be recovered by back-extraction, autodetachment (heterogeneous system), adsorption, distillation, membranes, magnetic or electrical field after their applications. Besides, regeneration of the hydrophilic [Bmim]Ac and [Bmim] Ac/ $\mathrm{ZnAc}_{2}$ after oil denitrogenation was carried out by diluting them with water while those hydrophobic $N$-compounds were repelled from the system [47], and the dilution process was followed by simple distillation. Among these ways, back-extraction is regarded as an easy-to-use method free of complex equipment. Under the above separation conditions, the two ionic liquids of $[\mathrm{HHqu}]\left[\mathrm{HSO}_{4}\right]$ and $[\mathrm{HBth}]\left[\mathrm{HSO}_{4}\right]$ containing pyridine, quinoline, or aniline were further recovered by back-extraction in order to evaluate their reusability. Among the potential extractants, alcohols and ketones were first abandoned because of their high mutual solubility with ionic liquids; aromatic compounds (benzene or toluene) and haloalkanes were also not considered because they are more toxic. Compared with esters, ether has a lower boiling point, which is easy to recover and reduces the energy consumption in the post-treatment process. More importantly, it can not only form two phases with ionic liquids quickly, but it can also extract three kinds of target components well.

The specific recovery process was carried out as follows: after the denitrogenation experiment was completed, the oil sample and ionic liquid are separated with a separatory funnel, and then, the ionic liquid phase (lower phase) was collected and extracted with equivolume ether. Through the second bi-phase separation, the ionic liquid phase was obtained and distilled under reduced pressure to remove the residual ether. After thorough 
dryness, the recovered ILs were used for the next denitrogenation experiment after being diluted with water, and corresponding $\mathrm{N}$-removal efficiency was determined in five cycles. The reusing investigation results of $[\mathrm{HHqu}]\left[\mathrm{HSO}_{4}\right]$ or $[\mathrm{HBth}]\left[\mathrm{HSO}_{4}\right]$ for removing pyridine, quinoline, or aniline are shown in Figure 8a-c, respectively. It can be seen that the effect of removing performance of the ILs for three target objects gradually decreases after being reused for five times. The experimental results showed that the denitrogenation efficiency of 8-hydroxyquinoline bisulfate for pyridine and aniline, together with benzothiazole bisulfate for quinoline, were $89.34 \%, 87.34 \%$, and $84.34 \%$, respectively. With the increase in reuse times, the amount of nitrogenous compounds extracted in the ionic liquid will increase, resulting in a reduction in the denitrogenation effect of the latter. If the N-removal efficiency reduces to be lower than $80 \%$, operators can improve the purity of [HHqu][ $\left.\mathrm{HSO}_{4}\right]$ or $[\mathrm{HBth}]\left[\mathrm{HSO}_{4}\right]$ by enlarging the volume of ether or increasing the number of backextraction times. Above results also prove that the interaction between acidic ionic liquids and weakly basic target substances is reversible. In the process of back extraction, with organic solvents such as ethers, the balance between ionic and molecular states of the three objects will move to the direction of molecular state because lowly polar solvents remove the target substances in the latter state continuously.
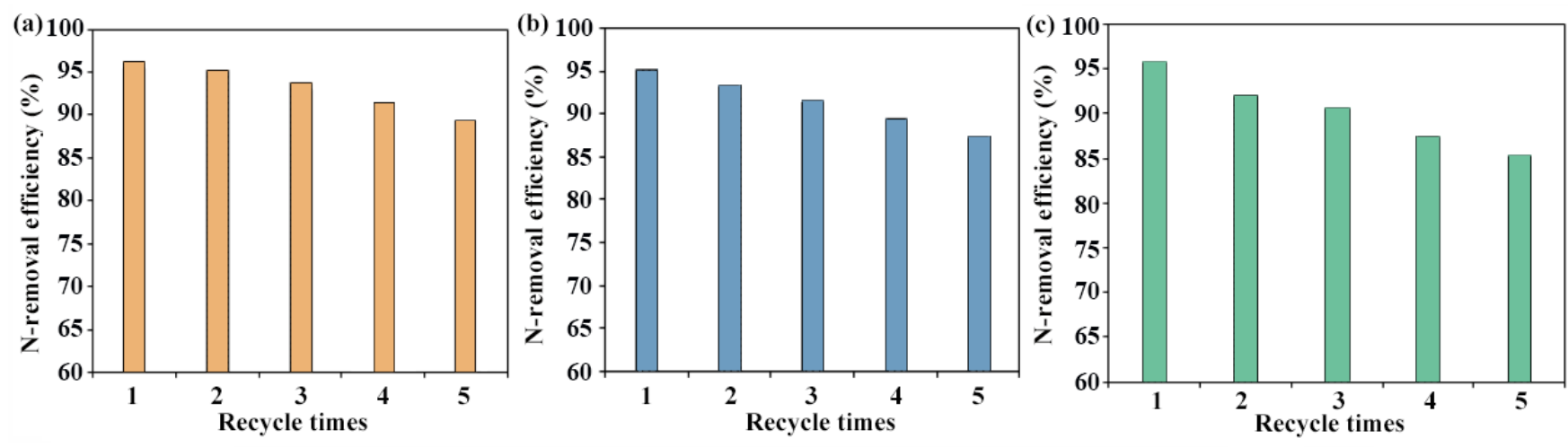

(d)
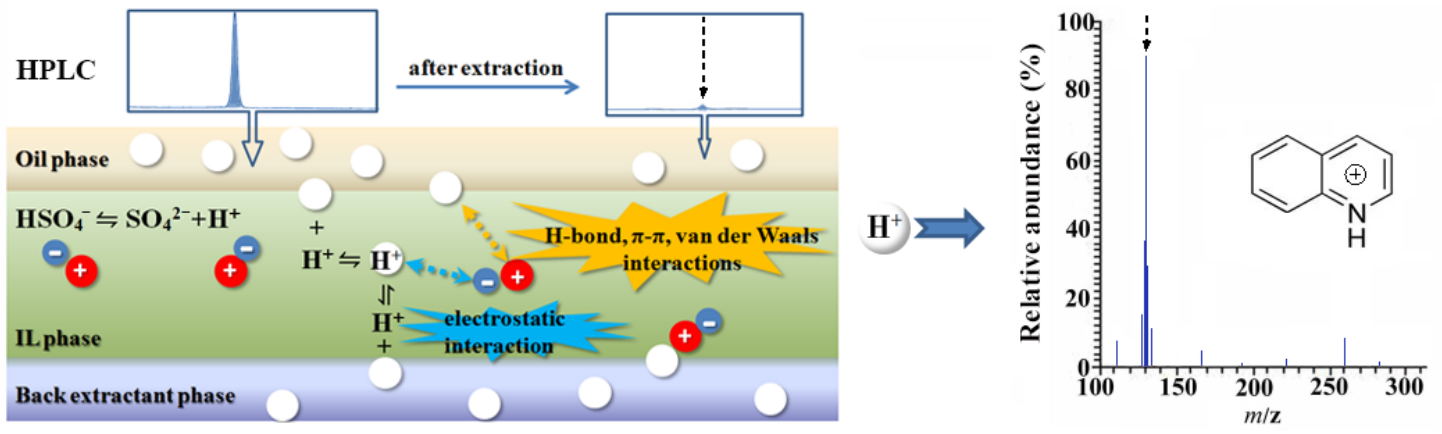

Figure 8. N-removal efficiency of the best IL in different recycle times for (a) pyridine, (b) quinoline, (c) aniline; (d) extraction mechanism in this study (white balls: targets, blue balls: IL anions, red balls: IL cations) under HPLC and MS analysis.

Finally, in order to investigate the possibility that the targets become protonated under the effect of acidic anion of the IL during extraction, the oil phase, containing quinoline before and after extraction, together with the mixture of quinoline and [HBth][ $\left.\mathrm{HSO}_{4}\right]$, were analyzed by a Waters Alliance 2695-2996 high-performance liquid chromatography (HPLC) system (Waters, Milford, MA, USA), coupled with UV detector under the developed conditions (Waters $\mathrm{C}_{18}$ column, $3.9 \times 150 \mathrm{~mm}, 5 \mu \mathrm{m} ; 60 \%$ methanol aqueous solution; $30{ }^{\circ} \mathrm{C} 10 \mu \mathrm{L} ; 225 \mathrm{~nm}$ ), which were further identified by Waters Quattro Premier XE triquadrupole mass spectrometer (MS) in positive ion mode after HPLC analysis. It can be found from Figure $8 \mathrm{~d}$ that the main chromatographic peak area belonging to target $\mathrm{N}$-compound (retention time $=6.16 \mathrm{~min}$ ) was significantly reduced, and the positive ion peak of protonated quinoline $\left(\mathrm{C}_{9} \mathrm{H}_{8} \mathrm{~N}^{+}, m / z=130.16\right)$ has been checked in the mixture; no 
irreversible ion-exchange and structure transformation occur in such a mild N-removal process, and the protonation also exists in other similar applications of acidic ILs (e.g., substituted imidazole phosphates in [38]). Considering the above experimental results and similar extraction mechanisms in $\mathrm{H}_{2} \mathrm{PO}_{4}$-based ILs, the mechanism in this study can be depicted as Figure 8d.

\subsection{N-Removal by the Tablets of Immobilized IL}

In recent years, more and more immobilized ILs are being used in separations because of easy recovery and less loss/residue during operation $[48,49]$. In this section, the sorption tablets containing IL were prepared to remove $N$-compound through solid-phase extraction on the basis of our previous method [50] and above research results, which aimed to provide more programs and options for researchers. Taking the extraction of pyridine by $[\mathrm{HBth}]\left[\mathrm{HSO}_{4}\right]$ as an example, multi walled carbon nanotubes were used as the carriers for the immobilized IL, which was loaded in a ultrasound-assisted way [51]. In detail, $600 \mathrm{mg}$ MWCNTs were thoroughly dispersed in $300 \mathrm{~mL}$ ethanol solution of [HBth][HSO $\mathrm{HS}_{4}$ $(1.5 \mathrm{mg} / \mathrm{mL})$ by sonication $(120 \mathrm{~W})$ for $20 \mathrm{~min}$, and then, the whole system was magnetically stirred under $30^{\circ} \mathrm{C}$ for $12 \mathrm{~h}$, and ethanol was totally removed under vacuum. After that, ethyl cellulose (EC) was mixed with the dried complex of IL-MWCNTs, evenly with the mass ratio of 0.05:0.10 (g/g, EC: IL-MWCNTs), and their powders (200 mesh) were pressed in a stainless steel mold with a diameter of $13 \mathrm{~mm}$ under the pressure of $15 \mathrm{MPa}$ for $3 \mathrm{~h}$. Finally, the immobilized IL complex tablets containing $42.9 \mathrm{mg}$ IL each piece, with the thinness of $2 \mathrm{~mm}$ and weight of $0.15 \mathrm{~g}$, could be obtained, which was placed in the oil sample for extraction. According to the mass ratio of IL to oil (1:10) in the Section 4.1.2, one tablet should treat $429 \mathrm{mg}$ oil here; however, the volume of oil was somewhat small for such a tablet. Therefore, the concentration of simulated oil containing quinoline was diluted to be half of its original concentration (the nitrogen content in the solution was $75 \mathrm{mg} / \mathrm{L}$ ), which was extracted by the tablet in the shaker, under room temperature, for $200 \mathrm{~min}$. Besides, $130 \mathrm{rpm}$ was selected because the tablet was stable in this shaking speed [49]. After measurement for the residual concentration of quinoline in the sample, its final N-removal efficiency was determined as $90.9 \%$. Though it did not reach the levels of separation performance and speed as ideally as those in the liquid-liquid extraction by the same IL, the whole process, together with post-treatment, was more easily operated; moreover, another unused tablet could be conveniently added in the oil for further improvement of N-removal efficiency.

\section{Conclusions}

For the first time, the aqueous solutions of ILs were used in single extraction, two-step extraction and solid phase, simultaneously, for three representative $N$-compounds in the stimulated oils. A series of IL solutions were comprehensively screened for their extraction performance and compared with current reports. As for the results, benzothiazole bisulfate $[\mathrm{HBth}]\left[\mathrm{HSO}_{4}\right]$ was selected as the most ideal ionic liquid for removing pyridine and aniline, and benzothiazole bisulfate $\left[\mathrm{HBth}_{[}\left[\mathrm{HSO}_{4}\right]\right.$ was found as the best one for removing quinoline from simulated oil. Furthermore, the main operational parameters were investigated successively, including mass ratio of IL to water, mass ratio of IL to oil, and temperature. The separation kinetic data can be better fitted by pseudo-first model, and it was found that the extraction speed of quinoline by $[\mathrm{HBth}]\left[\mathrm{HSO}_{4}\right]$ solution was higher than that of pyridine or aniline by $[\mathrm{HHqu}]\left[\mathrm{HSO}_{4}\right]$ solution. After efficient recovery by back-extraction, the ILs can be reused in repeated experiments. At last, the immobilized IL, in complex adsorbent tablets based on carbon nanotubes, can be successfully employed to remove target $N$-compound. As a whole, the research laid the foundation for further large-scale denitrogenation applications of ILs in various modes.

Author Contributions: This work presented here was carried out with collaboration among all authors. Methodology, Z.Z., Y.L. and J.G.; software, J.G., Y.L. and A.Y.; writing-original draft, 
Z.Z. and J.G.; writing-review and editing, A.Y. and H.S.; validation, H.S.; funding acquisition and supervision, S.Y. All authors have read and agreed to the published version of the manuscript.

Funding: This work is supported by Sichuan Science and Technology Program (No. 2021YFG0276).

Institutional Review Board Statement: Not applicable.

Data Availability Statement: The data presented in this study are available on request from the corresponding author.

Acknowledgments: We are grateful to all employees of this institute for their encouragement and support of this research. Special thanks to School of Chemical Engineering, Sichuan University for the FT-IR technical assistance.

Conflicts of Interest: The authors declare no conflict of interest.

\section{References}

1. Ahmed, I.; Jhung, S.H. Adsorptive desulfurization and denitrogenation using metal-organic frameworks. J. Hazard. Mater. 2016, 301, 259-276. [CrossRef]

2. Liu, Y.; Wang, W.; Hu, Q.; Zhu, Y.; Deng, J.; Tian, S. Characterization of basic nitrogen aromatic species obtained during fluid catalytic cracking by fourier transform ion cyclotron resonance mass spectrometry. China Pet. Process. Petrochem. Technol. 2012, 14, 18-24.

3. Klein, G.C.; Angström, A.; Rodgers, R.P.; Marshall, A.G. Use of saturates, aromatics, resins, and asphaltenes (sara) and non-basic nitrogen fractions analyzed by negative-ion electrospray ionization fourier transform ion cyclotron resonance mass spectrometry. Energy Fuels 2010, 24, 2545-2553.

4. Gu, X.H.; Mao, X.F.; Zhao, Y. Study on the basic nitrogen compounds from coal-derived oil. J. Coal Sci. Eng. 2013, 19, 83-89. [CrossRef]

5. Ahmed, I.; Jhung, S.H. Remarkable adsorptive removal of nitrogen-containing compounds from a model fuel by a graphene oxide/MIL-101 composite through a combined effect of improved porosity and hydrogen bonding. J. Hazard. Mater. 2016, 314, 318-325. [CrossRef]

6. Mu, L.; Wang, Y.; Cao, P.; Fan, Y.; Wang, L.; Liu, B.; Liu, M.; Yang, L.; Zhao, D. Removal of nitrogen and adsorption kinetics in shale oil by modified silica gel. Ion Exch. Adsorpt. 2019, 35, 260-269.

7. Fernando, S.; Hall, C.; Jha, S. NO $\mathrm{N}_{\mathrm{x}}$ reduction from biodiesel fuels. Energy Fuels 2006, 20, 376-382. [CrossRef]

8. Lu, X.; Song, C.; Jia, S.; Tong, Z.; Tang, X.; Teng, Y. Low-temperature selective catalytic reduction of $\mathrm{NO}_{\mathrm{X}} \mathrm{with}^{\mathrm{NH}} \mathrm{H}_{3}$ over cerium and manganese oxides supported on $\mathrm{TiO}_{2}$-graphene. Chem. Eng. J. 2015, 260, 776-784. [CrossRef]

9. Chand, V. Conservation of energy resources for sustainable development: A big issue and challenge for future. In Environmental Concerns and Sustainable Development; Shukla, V., Kumar, N., Eds.; Springer: Singapore, 2020.

10. Han, S.; Zhou, T.; Chai, Y.; Zhou, H.; Liu, C. Inhibition effects of quinoline, indole and carbazole on HDS of 4,6-DMDBT over Ni-Mo catalyst. Acta Petrol. Sin. 2010, 26, 177-183.

11. Furimsky, E.; Massoth, F.E. Hydrodenitrogenation of Petroleum. Catal. Rev. 2005, 47, 297-489. [CrossRef]

12. James, G.S. Desulfurization, denitrogenation, and demetalization. In The Refinery of the Future, 2nd ed.; Elsevier: London, UK, 2020.

13. Zhuang, S.; Guo, L.; Liang, J.; Zhang, Y. The development of non-hydrodenitrogenation technology of petroleum products. Refin. Chem. Ind. 2006, 17, 13-16.

14. Zhao, B.; Yuan, S.; Wang, Q. Research progress of shale oil composition and processing technology in China. Chem. Eng. Des. Commun. 2018, 44, 249-250.

15. Jin, K.S.; Jin, C.Y. Separation of nitrogen heterocyclic compounds from model coal tar fraction by solvent extraction. Sep. Sci. Technol. 2005, 40, 2095-2109.

16. Hwang, I.C.; Kim, K.L.; Park, S.J.; Han, K.J. Liquid liquid equilibria for binary system of ethanol +hexadecane at elevated temperature and the ternary systems of ethanol + heterocyclic nitrogen compounds + hexadecane at 298.15 K. J. Chem. Eng. Data 2007, 52, 1919-1924. [CrossRef]

17. Glaucia, H.C.P.; Yuan, R.; de Klerk, A. Nitrogen Removal from Oil: A Review. Energy Fuels 2017, 31, 14-36.

18. Jin, C.Y.; Yuan, L.; Li, N.; Pan, J. Removal of basic nitrogen compounds from diesel by solid superacids. Ind. Catal. 2010, 18, 51-54.

19. Zhang, J.; Xu, J.; Qian, J.; Liu, L. Denitrogenation of straight-run diesel with complexing extraction. Pet. Sci. Technol. 2013, 31, 777-782. [CrossRef]

20. Tang, X.; Hu, T.; Li, J.; Zhang, Y.; Chen, L. Progresses in the denitrogenation of diesel oil by complexation. Petrochem. Technol. 2014, 43, 843-847.

21. Zheng, L.; Yan, G.; Huang, Y.; Wang, X.; Long, J.; Li, L.; Xu, T. Visible-light photocatalytic denitrogenation of nitrogen-containing compound in petroleum by metastable $\mathrm{Bi}_{20} \mathrm{TiO}_{32}$. Int. J. Hydrogen Energy 2014, 39, 13401-13407. [CrossRef]

22. Zheng, L.P.; Huang, B. Photocatalytic denitrogenation of model oil over $\mathrm{Cu}_{2} \mathrm{O} / \mathrm{TiO}_{2}$. Chin. J. Struct. Chem. 2013, 32, 1131-1138. 
23. Qi, Q.; Li, P.; Zhang, Q.; Zhao, S. Progress of research in microwave technology application in petroleum processing. Petrochem. Technol. Appl. 2009, 27, 176-180.

24. Sun, J.; Xiu, P.; Cong, R.; Dong, H.; Wang, C.; Wang, L.; Liu, D. Reaction performance of nitrogen removal adsorption from the coking wax oil with activation resin. Chem. Eng. Oil Gas 2014, 43, 234-240.

25. Wang, Y.; Chi, Z. Research on nitrogen adsorption removal performance of mesoporous molecular sieve Al-MCM-41. Petrochem. Technol. Appl. 2014, 32, 113-117.

26. Morales, M.; Borgne, S.L. Protocols for the isolation and preliminary characterization of bacteria for biodesulfurization and biodenitrogenation of petroleum-derived fuels. In Hydrocarbon and Lipid Microbiology Protocols; McGenity, T., Timmis, K., Nogales, B., Eds.; Springer: Berlin/Heidelberg, Germany, 2014.

27. Seddon, K.R. Ionic liquids for clean technology. J. Chem. Technol. Biotechnol. 1997, 68, 351-356. [CrossRef]

28. Sheldon, R.A. Green solvents for sustainable organic synthesis: State of the art. Green Chem. 2005, 7, 267-278. [CrossRef]

29. Abro, R.; Abro, M.; Gao, S.; Bhutto, A.W.; Ali, Z.M.; Shah, A.; Chen, X.; Yu, G. Extractive denitrogenation of fuel oils using ionic liquids: A review. RSC Adv. 2016, 6, 93932. [CrossRef]

30. Huh, E.S.; Zazybin, A.; Palgunadi, J.; Ahn, S.; Hong, J.; Kim, H.S.; Cheong, M.; Ahn, B.S. Zn-containing ionic liquids for the extractive denitrogenation of a model oil: A mechanistic consideration. Energy Fuels 2009, 23, 3032-3038. [CrossRef]

31. Chen, X.; Yuan, S.; Abdeltawab, A.A.; Al-Deyab, S.S.; Zhang, J.; Yu, L.; Yu, G. Extractive desulfurization and denitrogenation of fuels using functional acidic ionic liquids. Sep. Purif. Technol. 2014, 133, 187-193. [CrossRef]

32. Lui, Y.Y.; Cattelan, L.; Player, L.C.; Masters, A.F.; Perosa, A.; Selva, M.; Maschmeyer, T. Extractive denitrogenation of fuel oils with ionic liquids: A systematic study. Energy Fuels 2017, 31, 2183-2189. [CrossRef]

33. Zhou, X.S.; Liu, J.B.; Luo, W.F.; Zhang, Y.W.; Song, H. Novel Brønsted-acidic ionic liquids based on benzothiazolium cations as catalysts for esterification reactions. J. Serb. Chem. Soc. 2011, 76, 1607-1615. [CrossRef]

34. Królikowska, M.; Królikowski, M.; Domańska, U. Effect of cation structure in quinolinium-based ionic liquids on the solubility in aromatic sulfur compounds or heptane: Thermodynamic study on phase diagrams. Molecules 2020, 25, 5687. [CrossRef]

35. Peng, L.; Yao, S.; Pu, L.; Yao, T.; Chen, C.; Song, H. New Brønsted-acidic ionic liquids based on 8-hydroxyquinoline cation as catalysts for the esterification reaction of $n$-hexylic acid. Adv. Eng. Res. 2015, 9, 257-260.

36. Zhou, Z.Q.; Li, W.S.; Liu, J. Removal of nitrogen compounds from fuel oils using imidazolium-based ionic liquids. Petrol. Sci. Technol. 2017, 35, 45-50. [CrossRef]

37. Asumana, C.; Yu, G.; Guan, Y.; Yang, S.; Zhou, S.; Chen, X. Extractive denitrogenation of fuel oils with dicyanamide-based ionic liquids. Green Chem. 2011, 13, 3300-3305. [CrossRef]

38. Wang, H.; Xie, C.; Yu, S.; Liu, F. Denitrification of simulated oil by extraction with $\mathrm{H}_{2} \mathrm{PO}_{4}$-based ionic liquids. Chem. Eng. J. 2014, 237, 286-290. [CrossRef]

39. Zhao, N.; Liu, D.; Li, Z.; Guo, Z.; Lou, B.; Yu, R.; Wang, F. Removal of nitrogen compounds from diesel fraction of coal tar with deep eutectic solvents. Acta Petrol. Sin. 2020, 36, 410-419.

40. Liu, J. Synthesis and denitrogenation performance of acetamide-based coordinated ionic liquid. Fine Chem. 2020, 37, $391-396$.

41. Yang, H.L.; Chen, J.; Zhang, D.L.; Wang, W.; Cui, H.M.; Liu, Y. Kinetics of cerium(IV) and fluoride extraction from sulfuric solutions using bifunctional ionic liquid extractant (Bif-bi nctional extractant Bit-ILE) $\left[\mathrm{A}_{336}\right]\left[\mathrm{P}_{204}\right]$. Trans. Nonferrous Met. Soc. China 2014, 24, 1937-1945. [CrossRef]

42. Xie, L.L.; Favre-Reguillon, A.; Pellet-Rostaing, S.; Wang, X.X.; Fu, X.Z.; Estager, J.; Vrinat, M.; Lemaire, M. Selective extraction and identification of neutral nitrogen compounds contained in straight-run diesel feed using chloride based ionic liquid. Ind. Eng. Chem. Res. 2008, 47, 8801-8807. [CrossRef]

43. Tang, J.; Liang, S.W.; Dong, B.; Li, Y.; Yao, S. Extraction and quantitative analysis of tropane alkaloids in Radix physochlainae by emulsion liquid membrane with tropine-based ionic liquid. J. Chromatogr. A 2019, 1583, 9-18. [CrossRef]

44. Gao, S.; Fang, S.; Song, R.; Chen, X.; Yu, G. Extractive denitrogenation of shale oil using imidazolium ionic liquids. Green Energy Environ. 2020, 5, 173-182. [CrossRef]

45. Perez, A.M.G.; Rojas, M.F.; Díaz, L.A.C. Ionic liquid [BMIM][Cl] immobilized on cellulose fibers from pineapple leaves for desulphurization of fuels. Adv. Mater. Lett. 2019, 10, 334-340. [CrossRef]

46. Chen, C.; Li, X.; Yan, X.; Tian, M. Solid-phase extraction of aristolochic acid I from natural plant using dual ionic liquidimmobilized zif-67 as sorbent. Separations 2021, 8, 22. [CrossRef]

47. Chen, C.; Feng, X.T.; Yao, S. Ionic liquid-multi walled carbon nanotubes composite tablet for continuous adsorption of tetracyclines and heavy metals. J. Clean. Prod. 2021, 286, 124937. [CrossRef]

48. Hampel, S.; Kunze, D.; Haase, D.; Krmer, K.; Büchner, B. Carbon nanotubes filled with a chemotherapeutic agent: A nanocarrier mediates inhibition of tumor cell growth. Nanomedicine 2008, 2, 175-182. [CrossRef]

49. Zhu, D.Z.; Sun, D.M.; Wang, S.L.; Sun, X.Y.; Ni, Y.M. Absorption spectra analysis in the degradation process of quinoline in aqueous solution by VUV lights. Spectrosc. Spectr. Anal. 2009, 29, 1933-1936.

50. Li, H.P.; Wang, W.Y. Determination of the phenylamine concentration in waste water by ultraviolet differential spectrophotometry method. Environ. Monit. China 2011, 27, 28-29.

51. Christopher, S.F.; William, H.B.; Brent, L.I.; Eric, A.; Christopher, S.F. Organic Chemistry, 8th ed.; Brooks Cole: Boston, MA, USA, 2018. 